This is a self-archived - parallel published version of this article in the publication archive of the University of Vaasa. It might differ from the original.

\title{
The Effects of Financial Education : Evidence from Finnish Lower Secondary Schools
}

\author{
Author(s): Kalmi, Panu \\ Title: $\quad$ The Effects of Financial Education : Evidence from Finnish Lower \\ Secondary Schools \\ Year: $\quad 2018$ \\ Version: Accepted manuscript \\ Copyright Wiley (C) This is the peer reviewed version of the following article: \\ Kalmi, P., (2018). The Effects of Financial Education : Evidence \\ from Finnish Lower Secondary Schools. Economic Notes 47(2-3), \\ 353-386, which has been published in final form at \\ https://doi.org/10.1111/ecno.12114. This article may be used for \\ non-commercial purposes in accordance with Wiley Terms and \\ Conditions for Use of Self-Archived Versions.
}

\section{Please cite the original version:}

Kalmi, P., (2018). The Effects of Financial Education : Evidence from Finnish Lower Secondary Schools. Economic Notes 47(2-3), 353-386. https://doi.org/10.1111/ecno.12114 


\section{The Effects of Financial Education: Evidence from Finnish Lower Secondary Schools}

Word count: 11,539

Panu Kalmi

Professor, Department of Economics and Business Law, Faculty of Business Studies

University of Vaasa, PO Box 700, 65101 Vaasa, Finland

panu.kalmi@uva.fi

$\underline{\text { Tel. }} \pm \underline{358447123049}$

\section{Abstract}

We study the effects of a peer-to-peer learning environment designed for lower secondary schools that provides financial education using games, videos and other materials provided online. We exploit a quasi-experimental setting with a control group to evaluate the effects of the learning environment and to distinguish them from the effects of a general economics course. We use two different samples from subsequent years to check the robustness of the results. Our results demonstrate the positive effects of financial education on financial knowledge, but no significant effects are shown in terms of savings behaviour. Further, although we find that girls improve their scores much more than boys after the educational intervention, we also find that this results from general education rather than from the specific intervention. Finally, we find that increased knowledge and enhanced savings behaviour are strongly correlated, supporting the notion that financial education holds promise for changing financial behaviour.

JEL Codes: A21, D14, 121 
Acknowledgement: The author gratefully acknowledges financial support from the Academy of Finland, Grant \# 269130 and \# 305292. He also expresses his gratitude to the management and teachers of Sedu, especially Ari Autio, for making this research possible.

\section{Introduction}

Numerous studies have shown that consumer financial literacy is correlated with desirable economic outcomes and that the importance of financial literacy is growing (Lusardi and Mitchell (2014) offer a survey of this literature). However, there is little consensus regarding how to improve this situation. Many argue that financial education should be provided at school, when a given age cohort can still be reached en masse (OECD, 2013; Lusardi, 2015). However, there is on-going debate regarding the effectiveness of financial education. One view, which we will refer to as "financial education pessimism", posits 1) that financial education does not improve knowledge and 2) that financial education does not improve financial behaviour (Willis, 2011).

Employing data from the Jumpstart Coalition in the US, Mandell and Schmid Klein (2009) provide support for the former proposition, as they find no evidence that students who attended a personal financial management course in high school exhibit financial literacy that is superior to that of a control group who did not attend the course. However, other studies have shown that financial education leads to substantial improvements in financial knowledge and that such learning may even spill over to parents (Walstad et al., 2010; Batty et al., 2015; Lührmann et al., 2015; Bruhn et al., 2016).

With regard to the second statement (i.e., that financial education does not improve financial behaviour), the evidence is also - and perhaps more - mixed. There is evidence that financial education in schools exerts a beneficial impact by reducing impulse shopping (Carlin and Robinson, 2012; Lührmann et al., 2015), but its effects on savings behaviour are unclear, with some studies finding 
positive effects (Batty et al., 2015; Bruhn et al., 2016) and others finding no effects (Lührmann et al., 2015). In addition, Bruhn et al. (2016) found some evidence on increased indebtedness and debt management problems associated with an otherwise (seemingly) successful large-scale financial education programme in Brazilian high schools.

However, the financial education programmes analysed in various studies vary substantially in scope and duration. Few studies evaluate issues related to quality of instruction, such as teaching methods and teacher interests, although there is a general consensus that the way education is delivered can make a substantial difference for learning (Heinberg et al. 2014). There is a paucity of research evaluating the impact of financial education in schools - particularly in levels below secondary school - and many of the studies that do address this topic employ small samples and sometimes no control groups (Collins and Odders-White, 2015; Miller et al., 2015).

In this paper, we present the results of an interesting experiment conducted in Finland, a country known for its good performance on the OECD's PISA examinations. However, financial education in Finnish schools is a relatively new topic, and Finland has not participated in PISA's financial relation module at the time of this writing (2017), although it intends to do so in 2018. Today, ninth-graders in Finland have mandatory economic education in their curriculum. This education consists of a combination of personal financial issues and more general economic issues. It is part of the social studies curriculum and is typically taught by teachers who have majored in history - and not economics - at the university.

We study a programme in which students in their last (ninth) year of mandatory lower secondary education attend a new financial education programme. This programme has two distinguishing characteristics. First, it is designed and administered by students at an upper secondary school (under the supervision of upper secondary-level teachers), which means that the age difference between the students and the educators is roughly three years. In that sense, the programme can be described as 
peer-to-peer learning. Second, there is intensive use of online games and videos in the programme, making it also an example of the use of games in teaching financial literacy (Maynard et al., 2012).

A nationwide and mandatory curriculum means that it is impossible to evaluate the impact of the programme relative to a control group in the same grade that receives no financial education. Therefore, the results of this research should thus be interpreted as the impact of using learning materials that are produced by a peer group, are delivered online, and involve the use of games.

We measure both changes in students' financial knowledge (literacy) and their self-reported financial behaviours, which in this case consist of their self-reported savings behaviour. The key problem in using savings behaviour is that the funds controlled by teenagers are usually limited and may be insignificant in relation to their future outcome; hence any returns earned on those are assets are likely to be trivial and spending them would possibly be the utility-maximizing decision. Despite this criticism, including savings behaviour as an outcome variable has been common in empirical studies (e.g., Batty et al., 2015; Lührmann et al., 2015; Bruhn et al., 2016). The inclusion of savings variables is likely to stem partly from pragmatic considerations: as financial knowledge is primary seen useful in the context of pursuing some desirable financial behaviour and, in general, building financial capabilities (Atkinson et al., 2007; Johnson and Sherraden, 2007; Sherraden et al., 2011), focusing solely on knowledge gains may be seen as too narrow. Regardless, the rationale for including savings variables should be the relevance of the variables in explaining decisions in adulthood. An argument has been made that a savings habit developed in childhood or youth may be sustained into adulthood (Collins and Odders-White, 2015). The empirical basis for this claim has been thin, but recent work by Brown and Taylor (2016) based on panel data for British individuals showed that self-reported childhood savings behaviour has a large impact on savings behaviour as an adult. 
The study also contributes to studies of gender differences and financial literacy (Bucher-Koenen et al., 2017). In a study of financial education intervention among Italian high school students, Becchetti et al. (2013) find that although males had higher levels of financial literacy, the educational intervention was more effective for females. In a study of Italian college students majoring in business studies, Bongini et al. (2015) find no evidence regarding gender differences. However, there appears to be little evidence regarding gender differences among pre-high school students.

This paper makes several notable contributions. First, it evaluates a peer learning programme in which upper secondary students provide educational material in the form of online material and games for lower secondary school students and thus offers evidence from an unusual and promising setting. The next contribution involves the use of two distinct samples, collected in subsequent years, that allows the stability of the findings from the first round to be evaluated. Such replication designs can improve (or help confirm) the external validity of datasets (Batty et al. 2015 present another example of such replication). Third, many previous studies on financial education have been from the US or from developing countries, and there are few studies from Europe (Miller et al., 2015). Finally, there are only few studies in this field at the pre-high school level (Collins and Odders-White, 2015). One downside of this study is that the setting precludes randomization of financial education. In addition, it is not possible to separate the effects of peer learning and online provision of financial education, and we observe the outcome of a combination of these two methods.

\section{Background}

The programme we evaluate in this paper is called Oma Onni ${ }^{1}$ ("Onni" for short), which has been organized by the Vocational Education Centre Sedu, which is based in Seinäjoki (in Southern

\footnotetext{
${ }^{1}$ A literal translation of Oma Onni is "Own Happiness", but there are other connotations. Onni is a common male first name in Finnish, and the program is frequently referred to as simply "Onni". "Oma" refers also to Oma Säästöpankki (literal translation: Own Savings Bank), which is sponsoring the program.
} 
Ostrobothnia, Western Finland). Sedu is a multidisciplinary three-year secondary-level educational institution that students typically enter directly after completing their mandatory 9-year schooling. It is an alternative to high school.

Onni was initiated in the spring of 2010 , when representatives of the foundations of two local savings banks ${ }^{2}$ in Southern Ostrobothnia contacted Sedu and proposed collaboration in the form of creating a new teaching environment providing instruction on personal financial capability. The first round of Onni occurred in 2010-2011 with a pilot study involving nine classes in three schools. The number of schools participating has grown gradually. This study focuses on the fifth and sixth editions of Onni, in particular, which occurred in the 2014-2015 and 2015-2016 academic years. The programme is offered exclusively in the area of operations of the sponsoring bank, Oma Säästöpankki.

Onni consists of an online learning environment in which Sedu students prepare financial educational materials, games and videos for the lower secondary school students. In addition to this material, Onni consists of school visits in which Sedu students introduce the learning environment in the lower secondary schools in one class of 45 minutes. Each class is visited by three Sedu students, two majoring in business administration and one in information technology (IT). The $9^{\text {th }}$ grade teachers are then invited to use the Onni learning environment in their teaching.

The students involved in the design of the Oma Onni programme are third-year students at Sedu, who are approximately 18 years of age and who are studying either IT or business administration. Both the business students and the IT students work together as a team, although there is some division of labour. The business students are responsible for developing the survey instrument and the content of the educational material that is posted on the Onni website. The IT students design and maintain the

\footnotetext{
${ }^{2}$ These two foundations are among the owners of Oma Säästöpankki, which was formed as a result of the mergers of local savings banks in different parts of Finland and is incorporated as a joint stock company.
} 
Onni-related webpages and organize the online survey questionnaire. As discussed above, both IT and business students visit the lower school classes together. The Sedu students are supervised by a team of Sedu teachers, which includes a lecturer in IT, a lecturer in business administration, and a lecturer in communications. The programme is overseen by a steering committee that consists of representatives of the sponsoring bank and foundations, school teachers, and representatives from Sedu.

The targets of the intervention are students in the final lower secondary grade $\left(9^{\text {th }}\right)$ and are approximately 15 years old. In this grade, these students must take one course in economics consisting of approximately 40 lecture hours. These lectures are given as part of the social studies curriculum. Of the 40 lectures, roughly one-half are related to the role of the consumer and personal finance, while the remaining lectures focus on macroeconomics. All the topics covered by Onni are related to the consumer and personal finance module of the lectures.

There are some standardized elements of Onni, such as the 45 -minute visit by Sedu students, and the material that can be accessed online is the same for everyone. The guiding idea is that teachers can gain more confidence in their teaching by having easier access to supportive material. In addition, the material and presentations are prepared by students who are roughly of the same age as ninth-class students, with the aim of increasing student motivation. However, the extent and ways teachers actually use the material can vary significantly. Anecdotal evidence based on qualitative interviews indicates that some teachers use the material intensively and develop their own material around Onni, and some use it to fill in lectures or as an extra assignment; however, in some schools, the 45-minute student visit and the two questionnaires are the main forms of Onni used. Unfortunately, we have no data on how much time teachers actually spend on Onni material, although we have one proxy for it (intensity of use, described below). The results should be interpreted as describing the effect of having access to the material. The actual use of Onni is endogenous and depends on teacher characteristics. 


\section{Data description}

\subsection{Research design}

Following the first and every other implementation of Onni, the learning outcomes have been evaluated using a questionnaire that is first administered before any teaching occurs (in September) and then repeated after conclusion of the coursework (in April). In previous versions, the questionnaire consisted of 90 items designed to measure knowledge. The identical questionnaire was used in both pre- and post-tests. There were certain individual- and group-level incentives rewarding good performance on the tests. The best performer in the school received an individual reward (consisting of the shares of mutual funds provided by the sponsoring savings bank). The best-performing class in the school also received movie tickets for each member of the class. Typically, the test results reveal significant improvements from the pre- to the post-tests.

However, there are serious problems in identifying learning outcomes solely by comparing the performance of students in pre- and post-tests without using a control group. The most obvious problem is that without taking part in Onni, students would nonetheless have taken an economics course as part of their standard curriculum. Without a control group, it is impossible to separate the effects of Onni from the general effects of having taken a course in economics. Second, the pre- and post-tests are more than six months apart in time. Fifteen-year-old students mature considerably over a six-month period, so at least some of the improvement may result from maturing. Finally, there is a distinct possibility that part of the improvement may result from students learning the questions in the first round and applying that knowledge in the second round.

The research design benefited from earlier data collection efforts and attempted to solve these problems. The most important change was to introduce a control group consisting of students in the same grade who did not participate in the programme. This change allows the effects of general 
education and the specific programme to be disentangled, as both groups receive general education but only one participates in the programme. It also solves the problem of students maturing because both groups obviously mature in the same manner and are on average the same age during both study periods.

There were also some constraints on the research design that were impossible to avoid because the programme had already been in place for some time. The ideal scenario would involve a sample in which the compositions of the treatment and control groups are randomly determined. However, this was not possible because the participating schools were predetermined. The control group was recruited among schools in geographically adjacent municipalities that did not participate in the Onni programme. However, the selection problem is not pronounced because eligibility and participation are determined by the branching area of Oma Säästöpankki: all schools in the municipalities where Onni is offered participate in the programme. Conversely, schools in the control group are not offered the possibility to participate in Onni. Thus, the decision of whether to participate is not made at the school but at the municipality level. This helps to avoid the problem that only those teachers who are most interested in Onni will adopt its use. Most schools where Onni is provided are in the region of Southern Ostrobothnia; most control schools are either in the same region or in the neighbouring region of Ostrobothnia. In terms of demographics and culture, the areas are rather similar. ${ }^{3}$

The problem of learning the questions from the pre-test is solved by using a different questionnaire in pre- and post-tests and was implemented by reducing the number of knowledge questions to 60 questions per questionnaire. We used 89 out of 90 questions from the previous questionnaire and supplemented these questions with 31 additional questions. ${ }^{4}$ The original questionnaire was developed

\footnotetext{
${ }^{3}$ One difference is that in Ostrobothnia, the Swedish-speaking population is larger than the Finnish-speaking population, whereas there is a tiny Swedish-speaking minority in Southern Ostrobothnia. However, all schools that participated in this study drew their students from the Finnish-speaking population.

${ }^{4}$ One question from the earlier 90-question set was deemed ambiguous and was replaced by a new question.
} 
by the students and teachers of Sedu. It had been used in several previous rounds of Onni, and questions have been selected according to their perceived quality, although they have not been formally validated. The new questions were designed by the students of Sedu with supervision from the teachers of Sedu and the researcher. Data from previous rounds of data collection were employed to separate the 29 questions so that they were - on average - of the same difficulty as the 60 remaining questions. The 31 new questions were not pre-tested, but the teacher-supervisors of the Onni project and the researcher used their own judgement in evaluating the difficulty of the questions.

In addition to the battery of knowledge-related questions, a new module was added that related to savings behaviours and attitudes consisting of 12 questions. The savings questions were not incentivized, whereas performance in knowledge questions was incentivized. ${ }^{5}$ This structure was employed because the knowledge questions could be objectively assessed, whereas the savings behaviour and attitudinal questions could not be independently verified and are thus subject to distortions (such as by the desire to provide socially responsible responses). Additionally, certain questions in the second questionnaire of the second year were related to previous academic performance and the number of books at home.

\subsection{Data collection}

For the 2014-2015 study, eleven schools in six different towns or municipalities were contacted to ask whether they were willing to serve as control schools, and ten of these initially agreed to participate. During that same year, there were 20 schools in 13 different towns or municipalities that participated in the Onni programme, and these schools formed the treatment group. In the 2015-2016 study, the Onni programme was broadened to include some additional schools, such that 22 schools from 14 different

\footnotetext{
${ }^{5}$ The incentive structure in Onni remained the same as in previous versions of the program. The incentives for the control group differed because only collective (classroom) incentives were provided, as the researcher did not learn the identities of the individual respondents (see more below).
} 
municipalities were invited. This group did not include schools that previously served as control schools. We contacted additional potential control schools regarding their willingness to serve as control schools. In the 2015-2016 edition, we invited 18 schools from 13 different municipalities to join the control group.

We collected data separately for two different cohorts of students, the first in 2014-2015 and the second in 2015-2016. The first round of data collection (pre-test) was performed in both academic years in September (in both 2014 and 2015), before the students attended any lectures in economics. The questionnaire consisted of 60 factual questions and 12 questions related to savings and attitudes towards money and banks. As background information, information regarding student-participants' names, class, school and gender were collected. The names were then changed into coded form, which allowed the pre- and post-test results to be matched to the same persons but simultaneously reduced the need for paperwork. ${ }^{6}$

The second round of data collection (post-test) was performed in April (in both 2015 and 2016), after the economics course had taken place. In April 2016, we also included questions related to school performance and the number of books at home.

Questionnaire data were collected electronically by means of internet survey. The recommended means of collecting the data was to bring the students to the classroom and to collect the data in a supervised environment, which occurred in the vast majority of cases.

\footnotetext{
${ }^{6}$ In the ethical guidelines of the Finnish Advisory Board on Research Integrity (FABRI), it is recommended that parental consent is requested when personal information on pupils is to be stored in a database; otherwise, the consent of teacher and school principal is sufficient (FABRI, 2009). Here, we opted for the former possibility because it was sufficient to match the information from two subsequent surveys for research design purposes, but the data were not matched to any external data source. However, the anonymized responses precluded individualized incentives for survey performance.
} 
In the 2014-2015 academic year, there were 2,127 respondents in the first round of data collection. In the second round, there were 1,816 respondents. A total of 2,386 respondents participated in one of the surveys, and of these, 1,557 respondents (65.3\%) participated in both surveys (Table 1 ). ${ }^{7}$

The numbers for the 2015-2016 academic year were comparable, in which 2,085 respondents completed the survey in the first round, whereas 1,794 completed the survey in the second round. In the end, 1,558 respondents (67.1\%) participated in both surveys. ${ }^{8}$

$* * * * * * * * *$ TABLE 1 AROUND HERE*************

Some of the attrition was the result of some schools dropping from the second survey. In the 2014-2015 academic year, there were 128 classes participating from 28 schools in the first survey, whereas in the second survey, there were 115 classes from 25 schools. An average of 16.6 students per class participated in the first survey and that number was 16.4 students in the second survey. In the 20152016 academic year, 136 classes from 29 schools participated in the first survey, and 122 classes from 26 schools participated in the second survey. An average of 15.4 students per class participated in the first survey, which dropped to 14.8 in the second survey. These results indicate that the drop in the number of participants is mainly the result of schools or classes dropping out of the sample, rather than a reduction in the number of students per class participating.

\subsection{Financial knowledge}

The questions on financial knowledge are divided into the following 6 subject areas: 1) work life, 2) consumption and online purchases, 3) money management and payments, 4) saving and investing, 5)

\footnotetext{
${ }^{7}$ In some cases, the students used incomplete or fake names, which prevented matching between the first and second surveys. For this reason, the true count of participating students is somewhat lower and the proportion of students taking both surveys is higher.

${ }^{8}$ Some students completed the survey more than once during one round of data collection in both years. There were 33 duplicate observations in the 2014-2015 academic year and 22 duplicates in the 2015-2016 academic year. Both observations were deleted in these cases. The numbers reported in Table 1 reflect these deletions.
} 
borrowing, and 6) insurance and entrepreneurship. Each section consists of 10 different questions, which means that there is a total of 60 questions in the questionnaire. Table 2 presents the number of correct responses in each of the subject areas for both rounds of data collection (the percentages of correct responses of components of financial knowledge can be obtained by multiplying by ten). Here, we use data that includes all valid responses. ${ }^{9}$ Examples of the questions are provided in the Appendix. The questions remained the same for both years of data collection.

In the 2014-2015 round of data collection, the differences between the treatment and control groups were insignificant five times out of six in the survey taken before any education was given, but for one item (savings and investment), the control group demonstrated significantly higher knowledge. After the treatment, the treatment group had a significantly higher proportion of correct responses for three subjects (working life, money management and payments, and insurance and entrepreneurship) than the control group, whereas the control group never had a statistically significantly higher fraction of correct responses in those subjects. Moreover, the difference between the groups in the total number of correct responses was significantly higher for the treatment group in the second round.

The results for the $2015-2016$ academic year are mostly similar to those from the previous year: there is one significant difference in the post-education period (consumption and online purchases) in favour of the control group, whereas there are two significant differences in favour of the treatment group (in money management and payments and in insurance and entrepreneurship). In addition, the difference in the total number of correct responses is statistically significant in favour of the treatment group.

$* * * * * * * * * * * \mathrm{TABLE} 2 \mathrm{AROUND} \operatorname{HERE} * * * * * * * * * * *$

${ }^{9}$ The results including only those respondents who answered in both rounds show a similar picture. 
Table 3 presents the distribution of responses divided into correct, "do not know" and incorrect responses for both pre- and post-test, separately for the whole sample, treatment and control groups, and for both years. An increase in the share of correct answers in the second survey is clearly evident for both groups, and both times this increase is larger for the treatment group. The magnitude of the increase is approximately 5.5 percentage points for the whole sample in 2014-2015 and 6.8 percentage points in 2015-2016. In both years, the increase is approximately 2 percentage points greater for the treatment group than for the control group. In terms of percentages, the increases are $12-16 \%$ for the treatment group and $8-11 \%$ for the control group. Thus, the gains are substantial but not huge. The preand post-test figures are not strictly comparable because the instruments were different and half of the questions in the latter survey had not been previously employed. Examining out-of-sample data (from previous years) on those questions that were used in previous editions indicates that the new questions were slightly more difficult than the questions in the first survey. Therefore, the increase in the overall share of correct responses somewhat understates the true extent of learning. In any case, the results support the hypothesis that some learning has occurred.

$* * * * * * * *$ TABLE 3 AROUND HERE*

\subsection{Savings behaviour and attitudes}

Several questions in the questionnaire related to savings behaviour and attitudes. These items were similar to previous studies of the savings behaviour of students (Batty et al., 2015; Lührmann et al., 2015; Bruhn et al., 2016). One such question was, "Do you save regularly for some goal? Yes / No / Cannot say". Another question related to savings was, "When you get money from your parents, how often do you save at least part of it? Never / sometimes / often / always / cannot say". A third savingsrelated question was, "Which one of the following statements best describes your relation with money? I want to use money to help my family and other people / I want to use money for myself / I want to buy 
everything I want / I want to save for the future / cannot say". Then, we formed a savings index on the basis of the responses to these three questions. For each of the three items, a respondent receives a value of one if he or she chooses the response in bold (only one response could be chosen for each question)..$^{10}$ The index takes values from 0 to 3 . Of course, one limitation of these questions, which is shared with the previous literature, is that these responses are self-reported.

The responses to these questions for both samples are presented in Table 4 . Approximately $50-60 \%$ of the respondents indicate that they would save for some goal. In comparisons between the treatment and control groups, there is a statistically significant difference in favour of the treatment group in the pre-test for the 2015-2016 term. Surprisingly, there is a statistically significant decline in the number of respondents who will save for some goal in the treatment group over the 2015-2016 term.

Between 35-45\% indicate that they save from their allowance often or always. In the 2014-2015 academic year, there was a statistically significant difference between the treatment and the control groups favouring the former in the post-education survey. However, in the pre-education survey during the 2015-2016 term, the members of the treatment group said more often that they save from their allowance but not so in the post-education survey. Approximately $50 \%$ indicated that when they receive money, they save for the future or use the money to help family or others instead of spending the money immediately. In this question, there were some differences in the 2014-2015 academic year between the treatment and control groups in both the pre- and post-education surveys. The changes over time were not statistically significant.

\footnotetext{
${ }^{10}$ In the third question, one might consider including the option "I want to use money to help my family and other people" as part of the index because it does not illustrate a spending attitude, although it may not depict savings behaviour either. This option was chosen only by approximately $5 \%$ of the respondents, and the results are not qualitatively affected by the inclusion of that option.
} 
The average values of the savings index hover approximately 1.4-1.5. There appears to be little change over time: in none of the cases are the changes statistically significant. There is a statistically significant difference between the treatment and control groups in the post-education survey for the 2014-2015 academic year and in the pre-education in survey for the 2015-2016 year in favour of the treatment groups in both instances. In the 2014-2015 academic year, it appears that a difference in the savings behaviour between the treatment and control groups emerges to the advantage of the former; however, in the 2015-2016 academic year, rather the opposite seems to occur.

\section{$* * * * * * * * * * * *$ TABLE 3 AROUND HERE $* * * * * * * *$}

\subsection{Independent variables}

Table 5 presents summary statistics for the treatment variables. In the pre-test for $2014-2015,72 \%$ of the students in the sample participated in Onni; despite sample attrition, the percentage of students participating remained the same in the post-test. In 2015-2016, the percentage of students participating in Onni is slightly lower (67\%); this percentage is the same in the pre- and post-tests.

There are two variables for the intensity of the treatment. For the 2014-2015 academic year, the measure is log-ins per student, which measures how many times each student in the treatment group logged in to the learning environment during the course. Naturally, this measure is only available for students who were in the treatment group - control group students are thus assigned a value of zero. This variable is based in IP-addresses and is available at the school level. For the $2015-2016$ academic year, the same measure was not available but was replaced by a similar (although broader) measure, i.e., how many "events" there were per student. An event can be a log-in, playing a game or video, taking a quiz, etc. For this reason, the intensity variable takes much higher values in the 2015-2016 data 
than in the 2014-2015 data. ${ }^{11}$ Moreover, this measure is somewhat endogenous and depends on teacher motivation: those teachers who use the learning environment more extensively in class may produce different results than those who use it less. ${ }^{12}$ We use this variable in some of the regressions.

Table 6 presents the remaining independent variables separately for the treatment and control groups and pre- and post-tests for both years. One of the control variables measures whether a student's family often engages in conversations involving issues related to money (yes / no / cannot say), and approximately $60 \%$ of the families in the survey indicate that this is the case. Further, the following question was related to long-term planning attitudes: "What is the best way to reach the goal you have set? Wait for things to just occur / planning ahead / there is no point in setting goals in advance / cannot say". Approximately $80 \%$ of the respondents gave the answer denoted in bold. Further, the students were asked if they received income from outside the home (e.g., if they had summer jobs or other temporary jobs; slightly less than $70 \%$ have such employment) or from parental allowances (approximately 35\% receive such allowances). Further, they were asked if they have bank accounts (approximately $80 \%$ have bank accounts). The measures of economic socialization and the sources of income are similar to the previous literature (e.g., Webley and Nyhus, 2006; Brown and Taylor, 2016). The role of psychological traits, such as planning, have been stressed by Fernandes et al. (2014), among others.

There were certain control variables that were introduced only in the post-test of the 2015-2016 academic year. These are the latest math grades, the average grades for all subjects, and dummy

\footnotetext{
${ }^{11}$ For two small schools, the values of the intensity variable were not available in the 2015-2016 data collection. ${ }^{12}$ To the extent that students use the learning environment in their leisure time using an internet connection other than those provided by the school, the use is not measured. However, interviews with Sedu teachers indicated that the bulk of the use of the learning environment is likely to take place in class.
} 
variables for the number of books at home (cf. Lührmann et al., 2015). The school grading system in Finland varies from 4 (worst) to 10 (best). The average latest math grade was 7.77 , and the average of all grades was 8.03. Although these figures are self-reported, the means are consistent with expectations, and no bias is detected. Approximately $40 \%$ of the students indicated that there were between 25 and 100 books at home; $37 \%$ of the students indicated that there were over 100 books at home, and $23 \%$ of students said there were fewer than 25 . The number of books at home is a measure for the socioeconomic background of the students that has been previously used in the OECD PISA tests.

Because this question was asked only in the post-test, we decided to impute the values to the pre-test to make this variable more useful in the regressions. However, doing so means that the variable is missing for those respondents who took the pre-test but not the post-test. For this reason, the number of observations regarding these variables is somewhat lower than for the other variables.

The table also includes t-tests between the means of the treatment and control groups. There are some differences between the treatment and control groups in 2014-2015. Discussions about money issues in the family are more likely in the treatment group than in the control group in the post-test (but not in the pre-test). Moreover, students in the treatment group are more likely to have earnings outside family in the pre-test than students in the control group (but this does not carry over to the post-test). In 20152016, students in the treatment group are more likely to have had discussions over money issues in the family than students in the control group in both the pre- and post-tests; they are more likely to have earnings outside the family in the pre-test (but in the post-test); and they less likely to have very few books at home and more likely to have plenty of books at their homes than students in the control group. Overall, there seems to be more similarities than differences between the two groups.

\section{Regression analysis}




\subsection{Regression specification}

In this section, we provide the results from the regression analysis. The main subject of interest is whether the treatment increases the knowledge scores and whether it influences savings behaviour. A key challenge is to uncover causal coefficients in those situations in which treatment has not been randomly assigned. However, it is notable that although assignment is not random, schools do not make the decision whether they participate in the treatment or not; as explained above, participation is determined by whether the school is located in the area in which Oma Säästöpankki operates.

Difference-in-difference estimation is a suitable specification for this purpose, as these types of estimations control for the starting values of the two distinct groups (treatment and control). The basic specification is

Outcome $_{i, t}=\alpha+\beta$ Onni $_{i, t}+\chi$ Post-education $_{\mathrm{t}}+\delta\left(\right.$ Onni $^{*}$ Post-education $_{i, t}+\phi$ female $_{i}+\gamma$ controls $_{\mathrm{i}, \mathrm{t}}+\varepsilon_{\mathrm{l}, \mathrm{t}}$, (eq. 1)

where the outcome variable is either knowledge (the number of correct responses) or self-reported savings behaviour. Onni (treatment status) and Female are dummy variables that do not change over time, whereas Post-education is essentially a time dummy to indicate the second round of data collection. The key parameter of interest is $\delta$, which tests whether the outcome variables of the treatment group are significantly different from those of the control group, given their starting levels. All regressions use the ordinary least squares (OLS) estimator, and we use heteroskedasticity and cluster robust standard errors.

We augment this basic specification in a variety of ways. We include an interaction term between Female and post-education to determine whether financial education has a differential impact on girls than on boys. In certain specifications, we include a three-way interaction to test the hypothesis that the 
gender differences in learning are related to the treatment rather than to education in general. In one of the specifications, we include measures for the intensity of the treatment. In the final specification, we include financial knowledge as an explanatory variable for savings behaviour, which is consistent with the notion that the ultimate purpose of improving knowledge is to influence behaviour.

\subsection{Financial knowledge}

We begin from those regressions in which the number of correct responses is the dependent variable and which use the data from the 2014-2015 academic year. Column (1) of Table 7 presents the results from the pre-test. The coefficient for Onni (treatment) is insignificant, suggesting that treatment and control schools begin at similar levels. Girls begin at a lower level of financial knowledge than boys - and present a difference of nearly 2 points - which is consistent with the oft-noted fact that females typically score lower on financial literacy tests than males (Bucher-Koenen et al., 2017). Most of the control variables are positively related to financial knowledge, except for having an allowance, which is negatively related to financial knowledge.

In column (2), we present the results for the cross-section of the post-test. Now, the Onni dummy is positive and significant, whereas the Female dummy is not significant. The coefficients of the control variables are largely the same as before.

Column (3) presents the baseline results. The main coefficient of interest - the interaction term between treatment and post-education - is positive and significant, which suggests that those in the treatment group (those participating in Onni) have (on average) scores that are 1.2 units higher than those in the control group. The coefficient for post-education suggests that attending a course on economics leads to scores that are higher by 2.1 units, on average. Against that background, participating in Onni makes a significant difference: students who participate in the treatment increase their score almost $60 \%$ more than those in the control group. 
Columns (1) and (2) together imply that the treatment may result in differential effects on boys and girls. The specification in column (4) picks up this issue and introduces an interaction effect between gender and post-education. It shows that girls improve their score after education by 2.2 points more than boys; thus, girls' improvement is approximately 3 times that of boys. Concurrently, the coefficient for Onni is of similar size as earlier.

The results regarding gender in specification (4) relates to financial education generally and is not related to the Onni programme. To test the possibility that there might be a differential effect of Onni across gender, we include in specification (5) a three-way interaction effect between Onni, Posteducation and Female. However, this coefficient is insignificant, and we do not include it in the final specifications of the table.

In specification (6), we include the continuous variable for the intensity of use alongside the Onni dummy and the interaction between Onni and Post-education. The interpretation is that we can estimate separate effects for having Onni in place and a different effect depending on the intensity with which Onni is used. Perhaps unsurprisingly, the effect of having the programme in place is not significant, whereas the continuous measure for the intensity of use is significant. To illustrate this effect, consider a school in which log-ins per student are one standard deviation higher than the mean (4.25 instead of 2.28). In such a school, the estimated increase in scores due to Onni would be 1.71 instead of 1.20 , which is the mean effect. However, the intensity variable may be prone to endogeneity problems (as discussed above) as well as measurement problems (because it is measured at the school level); therefore, the causal impact may be different.

$* * * * * * * * * * * * *$ TABLE 7 AROUND HERE

We then turn to the data from the 2015-2016 academic year (Table 8). The main difference here is that in certain specifications, we use additional control variables based on student school performance and 
the number of books at home. In addition, as explained above, the measure of intensity is somewhat different.

The results from the cross-sectional regressions are similar to those obtained from 2014-2015 data. Now, the treatment group began from a somewhat lower level than the control group (specification 1), which may have resulted because the treatment was not fully randomized. The coefficient for Female is also negative and significant, and control variables are mostly positive and significant. However, in the post-test, the situation has changed such that both treatment and Female dummies have positive coefficients (specification 2). Specification (3) introduces the variables covering school performance and the number of books at home. As might be expected, student grades are significant and positive in their own right and again change the sign of the Female coefficient, although their inclusion does not affect the Onni dummy ${ }^{13}$ Finally, the number of books at home is not a significant determinant of financial knowledge.

The baseline results are presented in specification (4), and as with the previous year, they indicate a significant increase in the knowledge scores of the treatment group compared with those of the control group. The estimated increase due to the treatment (1.43) is now somewhat larger in the previous year. Consistently with the results from the previous academic year (i.e., 2014-2015), the increase in financial knowledge is approximately $50 \%$ larger for those participating in the Onni programme than for those who took the standard course. In specification (5), we see that girls gain approximately 2 points more knowledge from economic education, on average. The results regarding Onni and Female are practically unaffected by including additional controls (specification 6 ), and the three-way interaction term is not significant (specification 7).

\footnotetext{
${ }^{13}$ School performance is strongly correlated with gender (girls perform better in school than boys), and including school performance controls dramatically reduces the coefficient for Female.
} 
Specification 8 includes the intensity variable. This time, both the interaction term between Onni and Post-education remains significant, and the intensity of treatment is also significant. The combined effect of these terms estimated at the mean level of intensity (26.93) is 1.35 , whereas if the intensity of treatment is increased by one standard deviation to 52.15 , the estimated effect becomes 1.83 .

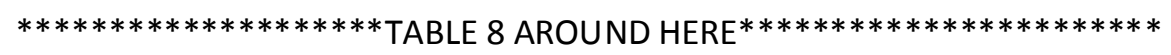

\subsection{Savings behaviour}

In Table 9, we present the results of regressions related to savings behaviours. We use similar specifications for financial knowledge and estimate the effects separately for the 2014-2015 and for 2015-2016 periods.

In column (1), we present the results relating to the pre-test. Some of the control variables (family talks about money, propensity to plan ahead, and earning income outside family) are positively and significantly related to savings; however, treatment and gender are not. In column (2), where the results related to the post-test are presented, treatment has a positive association with savings behaviour. The same applies to the Female dummy.

However, in specification (3), when we control for savings behaviour in the pre-test, we find that the increase in savings behaviour for the treatment group is not significant: only control variables are significant. The results from specification (4) suggest that girls change their savings behaviour in response to education more than boys; however, the negative sign of post-education suggests that the savings behaviour of boys decreases after the educational module. When education is separated into Onni and general education (specification 5), the coefficients are again insignificant.

The only instance when the interaction term between Onni and Post-education is significant in Table 9 is in column (6). However, this is coupled with a negative sign on the intensity of use, so that higher 
intensity actually deteriorates savings behaviour; already at one standard deviation above the mean intensity the net effect is negative, so this hardly qualifies as support for the positive effects of Onni on savings behaviour.

Finally, we introduce financial knowledge as an explanatory variable in specification (7). There is a clear positive correlation between the level of financial knowledge and savings behaviour.

\section{TABLE 9 AROUND HERE*}

In Table 10, we present the results of savings behaviour for the 2015-2016 academic year. The results for the pre- and post-tests separately are similar to those presented in Table 9, although the post-test coefficient for girls becomes negative when the school performance and books at home variables are added (column 3). The average grade of all subjects has a positive association with savings behaviour, as does the number of books at home, whereas the latest math grade is not significant.

From column (4) on, we present those results in which both rounds of data collection are used and the key coefficient is the interaction term between treatment and post-education. The interaction term turns out to be negative and significant in column (4), whereas the Onni dummy itself is positive and significant. Consistently with the results presented in Table 4, this result indicates that a) the beginning levels of savings between the control and treatment groups were different and $b$ ) the savings behaviour of the treatment group is deteriorating relative to the control group. The first result may result from the fact that treatment could not be randomized, and the second result is unexpected. Nonetheless, the negative coefficient on the interaction term survives in various specifications (except in (6)). However, it is notable (and different from the 2014-2015 period) that the variable related to intensity of use is positive and significant, although the intensity must be very high such that the point estimate of the Onni effect would become positive (let alone significant). 
In the final specification (9), there is again evidence that higher financial knowledge is positively related to savings behaviour. In addition, several of the control variables are positive and significant, including family talking about money, the propensity to plan ahead, earning income outside of the family, and (less consistently) having a bank account. In addition, the average grade for all subjects is related to savings and the number of books at home, whereas the most recent math grade is not. ${ }^{14}$

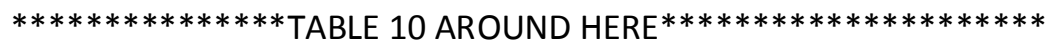

\section{Conclusions}

In this paper, we have studied the effects of financial education on financial knowledge and savings behaviour. Unlike many previous studies, we exploit a large sample and use a control group of students. We also replicate the research setting in the following year and are thus able to provide comparable evidence from two independent samples.

We measure the effects of a peer-to-peer learning environment, which augments the standard $9^{\text {th }}$ grade course in economics. This learning environment has several important features: it is created by slightly older students (peers) from a secondary-level educational institute, is provided online, and uses games and videos as part of its pedagogy. Any results should be interpreted as additions over the usual coursework, rather than as simply the general effects of the coursework.

We provide a quasi-experimental evaluation by using pre- and post-tests and a control group that does not participate in the learning environment. The results derived from using two different samples and two different estimators yield consistent results: the use of a peer-to-peer learning environment

\footnotetext{
${ }^{14}$ As a robustness check, we also attempted specifications in which the dependent variable is the first difference of the outcome variable (financial knowledge or savings behaviour). The results obtained using this method are virtually identical to those reported here. To save space, those results are omitted from this presentation but are available from the author.
} 
provides substantial improvements in financial knowledge. These effects are in addition to those obtained by traditional teaching methods, which are themselves already quite significant, which contradicts the pessimistic hypothesis that personal finance issues cannot be taught effectively. However, the other pessimistic hypothesis - that financial education does not lead to changes in financial behaviour - seems more valid. The results presented in this study are mixed at best and sometimes hint even at a negative relationship between financial education and financial-related behaviours. However, there is a positive relationship between measures of financial knowledge and savings behaviour, including in first differences. Thus, the two are not unrelated, although we cannot find evidence that the intervention influenced savings behaviour positively. ${ }^{15}$

There are also interesting results related to the debate on gender and financial literacy. In both years of data collection, girls initially presented lower average financial literacy than boys, but the girls were able to close this gap during the education period. However, this occurred both in the treatment and the control groups and was thus unrelated to the treatment as such. There were no significant results regarding gender and savings behaviour.

The key puzzle emerging in this study - and the general challenge for financial education - is why the positive knowledge gains do not translate into changes in behaviour. There may be several plausible explanations. One is that 15 -year-old students typically live with their parents and rarely make independent decisions of economic significance. Therefore, they may not perceive that their savings behaviour would make a real difference in their lives.

The second issue may be measurement. As the scrutinized behaviour is self-reported, students may be influenced by desirability bias and report what they think they should report rather than the truth. This

\footnotetext{
${ }^{15}$ This is consistent with Fernandes et al. (2014), who argue that most studies find a link between measures of financial literacy and financial behaviour but that the link between education and outcomes is more elusive.
} 
type of measurement error may mask true relationships, especially when the knowledge gains themselves are moderate in size. One way to remedy this issue is to design outcome variables based on students' behaviour in simulations, following Carlin and Robison (2012).

Third, the programme may simply be more geared to improve knowledge than to improve behaviour. Many financial education programmes operate on the premise that improved knowledge leads to changes in behaviour. Nonetheless, it may be that providing simple heuristics is more effective at changing financial behaviour than broader education (Drexler et al., 2014). However, ultimately it may be more useful for students to receive a more general education that they can later apply in various circumstances in their lives, which highlights that the outcomes should ideally be measured over a considerably longer period of time.

\section{References:}

A.Atkinson - S. McKay - S. Collard- E. Kempson (2007), "Levels of Financial Capability in the UK", Public Money \& Management, 27(1): 29-36.

M. Batty - J.M. Collins - E. Odders-White (2015), "Experimental Evidence on the Effects of Financial Education on Elementary School Students Knowledge, Behavior and Attitudes", Journal of Consumer Affairs 49(1): 69-95.

L. Becchetti - S. Caiazza - D. Coviello (2013), "Financial Education and Investment Attitudes in High Schools: Evidence from a Randomized Experiment", Applied Financial Economics, 23(10), 817-836.

P. Bongini - P. Trivellato - M. Zenga (2015), "Business Students and Financial Literacy: When Will the Gender Gap Fade Away?", Journal of Financial Management Markets and Institutions, 3(1): 13-30.

S. Brown - K. Taylor (2016), "Early Influences on Saving Behavior: Analysis of British Panel Data", Journal of Banking \& Finance, 63:1-14. 
M. Bruhn - L. de Souza Leão - A. Legovini - R. Marchetti - B. Zia (2016), "The Impact of High School Financial Education: Evidence from a Large Scale Evaluation in Brazil", American Economic Journal: Applied Economics, 8(4): 256-295.

T. Bucher-Koenen - A. Lusardi - R. Alessie - M. van Rooij (2017), “How Financially Literate Are Women? An Overview and New Insights", Journal of Consumer Affairs, 51: 255-283

B.I. Carlin - D.T. Robinson (2012), "What Does Financial Literacy Teaching Teach Us?" The Journal of Economic Education, 43(3): 235-247.

J.M. Collins - E. Odders-White (2015), “A Framework for Developing and Testing Financial Capability Education Programs Targeted to Elementary Schools", The Journal of Economic Education , 46(1): 105-120.

A.Drexler - G. Fischer - A. Schoar (2014), "Keeping It Simple: Financial Literacy and Rules of Thumb", American Economic Journal: Applied Economics, 6(2), 1-31.

FABRI (2009), Humanistisen, yhteiskuntatieteellisen ja käyttäytymistieteellisen tutkimuksen eettiset periaatteet ja ehdotus eettisen ennakkoarvioinnin järjestämiseksi, Helsinki: The Finnish Advisory Board on Research Integrity.

D. Fernandes - J.G. Lynch Jr. - R.G. Netemeyer (2014), "Financial Literacy, Financial Education, and Downstream Financial Behaviors", Management Science, 60(8), 1861-1883.

A. Heinberg - A. Hung - A. Kapteyn - A. Lusardi-A.S. Samek - J. Yoong (2014), “Five Steps to Planning Success: Experimental Evidence from US Households", Oxford Review of Economic Policy, 30(4), 697-724.

E. Johnson - M. S. Sherraden (2007), "From Financial Literacy to Financial Capability among Youth", Journal of Sociology and Social Welfare, 34, 119-146. 
M. Lührmann - M. Serra-Garcia - J. Winter (2015), "Teaching teenagers in finance: does it work?" Journal of Banking \& Finance, 54, 160-174.

A. Lusardi (2015), "Financial Literacy Skills for the 21st Century: Evidence from Pisa", The Journal of Consumer Affairs, 49(3): 639-659.

A. Lusardi - O. Mitchell (2014), "The Economic Importance of Financial Literacy: Theory and Evidence", Journal of Economic Literature, 52 (1): 5-44.

L. Mandell - L. Schmid Klein (2009), "The Impact of Financial Literacy Education on Subsequent Financial Behavior", Journal of Financial Counseling and Planning, 20(1): 15-24.

N.W. Maynard - P. Mehta - J. Parker - J. Steinberg (2012), “Can Games Build Financial Capability? Financial Entertainment: A Research Overview", Santa Monica, CA: RAND Corporation Working Paper WR963-SSA. Available from http://www.rand.org/pubs/working papers/WR963.html (last accessed December 28, 2016).

M. Miller - J. Reichelstein - C. Salas - B. Zia, (2015), "Can You Help Someone Become Financially Capable? A Meta-analysis of the Literature", World Bank Research Observator 30(2): 220-246.

OECD (2013), Financial Education for Youth and in Schools: OECD / INFE Policy Guidance, Challenges and Case Studies, Paris: Organization for Economic Cooperation and Development, and Russia Trust Fund for Financial Literacy and Education.

M.S. Sherraden - L. Johnson - B. Guo - W. Elliot III (2011), "Financial Capability in Children: Effects of Participation in a School-Based Financial Education and Savings Program", Journal of Family and Economic Issues, 32: 385-399. 
W.B. Walstad - K. Rebeck - R.A. MacDonald (2010), "The Effects of Financial Education on the Financial Knowledge of High School Students", The Journal of Consumer Affairs, 44(2):336-357.

P. Webley - E.K. Nyhus (2006), “Parents' Influence on Children's Future Orientation and Saving”, Journal of Economic Psychology, 27: 140-164.

L.E. Willis (2011), "The Financial Education Fallacy", American Economic Review 101(3): 429-434. 


\section{TABLES}

Table 1. Number of students that participated in the surveys

\begin{tabular}{|l|l|l|l|l|}
\hline Participation & $\begin{array}{l}\text { Number of } \\
\text { respondents, 2014- } \\
2015\end{array}$ & \%, 2014-2015 & $\begin{array}{l}\text { Number of } \\
\text { respondents, } \\
2015-2016\end{array}$ & \%, 2015-2016 \\
\hline Both surveys & 1,557 & 65.3 & 1,558 & 67.1 \\
\hline First survey only & 570 & 23.9 & 527 & 22.7 \\
\hline Second survey only & 259 & 10.9 & 236 & 10.2 \\
\hline Total & 2,386 & 100 & 2,321 & 100 \\
\hline
\end{tabular}

Note: Duplicate respondents were removed. 
Table 2. Correct responses by treatment and data collection round, 2014-2015 and 2015-2016: Means (standard errors in parentheses)

\begin{tabular}{|l|l|l|l|l|}
\hline & $\begin{array}{l}\text { Treatment group, } \\
2014-2015\end{array}$ & $\begin{array}{l}\text { Control group, } \\
2014-2015\end{array}$ & $\begin{array}{l}\text { Treatment } \\
\text { group, 2015- } \\
2016\end{array}$ & $\begin{array}{l}\text { Control } \\
\text { group, 2015- } \\
2016\end{array}$ \\
\hline Working life, Q1 & 4.66 & 4.67 & 4.58 & 4.64 \\
& $(.05)$ & $(.07)$ & $(.05)$ & $(.07)$ \\
\hline Working life, Q2 & $4.98^{* * *}$ & $4.71^{* * *}$ & 4.95 & 4.90 \\
& $(.05)$ & $(.08)$ & $(.05)$ & $(.07)$ \\
\hline Consumption and & 5.51 & 5.56 & $5.32^{* * *}$ & $5.58^{* * *}$ \\
online purchases, Q1 & $(.04)$ & $(.07)$ & $(.05)$ & $(.07)$ \\
\hline Consumption and & 5.48 & 5.44 & 5.55 & 5.50 \\
online purchases, Q2 & $(.05)$ & $(.08)$ & $(.05)$ & $(.07)$ \\
\hline Money management & 5.58 & 5.67 & 5.55 & 5.58 \\
and payments, Q1 & $(.05)$ & $(.07)$ & $(.05)$ & $(.07)$ \\
\hline Money management & $6.63^{* * *}$ & $6.29^{* * *}$ & $6.66^{* *}$ & $6.41^{* *}$ \\
and payments, Q2 & $(.05)$ & $(.08)$ & $(.06)$ & $(.08)$ \\
\hline Saving and investing, & $4.34^{* *}$ & $4.55^{* *}$ & 4.24 & 4.34 \\
Q1 & $(0.05)$ & $(0.09)$ & $(.06)$ & $(.08)$ \\
\hline Saving and investing, & 5.11 & 5.09 & 5.10 & 5.06 \\
Q2 & $(.05)$ & $(.09)$ & $(.05)$ & $(.08)$ \\
\hline Borrowing, Q1 & 4.70 & 4.73 & 4.54 & 4.62 \\
& $(.05)$ & $(.08)$ & $(.05)$ & $(.08)$ \\
\hline Borrowing, Q2 & 6.09 & 6.00 & 6.23 & 6.29 \\
& $(.05)$ & $(.08)$ & $(.05)$ & $(.08)$ \\
\hline Insurance and & 4.24 & 4.17 & 4.21 & 4.19 \\
entrepreneurship, Q1 & $(.05)$ & $(.07)$ & $(.05)$ & $(.07)$ \\
\hline Insurance and & $4.38^{* *}$ & $4.20^{* *}$ & $4.41^{* * *}$ & $4.01^{* * *}$ \\
entrepreneurship, Q2 & $(.05)$ & $(.08)$ & $(0.05)$ & $(.07)$ \\
\hline Total correct, Q1 & 29.02 & 29.34 & 28.43 & 28.94 \\
& $(.20)$ & $(.31)$ & $(.20)$ & $(.30)$ \\
\hline Total correct, Q2 & $32.67^{* *}$ & $31.74^{* *}$ & $32.90^{* *}$ & $32.16^{* *}$ \\
& $(.20)$ & $(.33)$ & $(.21)$ & $(.29)$ \\
\hline
\end{tabular}

Notes:

1) Q1: Questionnaire 1 (pre-test); Q2: Questionnaire 2 (post-test)

2) Number of observations are: 2014-15: Q1: Treatment group $N=1,533$, Control group $N=594 ; \mathrm{Q} 2$ : Treatment group $\mathrm{N}=1,302$, Control group $\mathrm{N}=514 ; 2015-2016$ : Q1: Treatment group $\mathrm{N}=1,406$, Control group $\mathrm{N}=678$; Q2: Treatment group $\mathrm{N}=1,198$, Control group $\mathrm{N}=597$.

3) The results of the t-test refer to pairwise comparisons of the treatment and control groups. Levels of significance: ${ }^{* *} 5 \%$; ${ }^{* *} 1 \%$. 
Table 3. The distribution of correct, do not know and incorrect responses in knowledge questions between pre- and post-test

\begin{tabular}{|l|l|l|l|l|l|l|}
\hline & $\begin{array}{l}\text { All } \\
\text { respondents, } \\
14-15\end{array}$ & $\begin{array}{l}\text { Treatment } \\
\text { group, 14- } \\
15\end{array}$ & $\begin{array}{l}\text { Control } \\
\text { group, 14- } \\
15\end{array}$ & $\begin{array}{l}\text { All } \\
\text { respondents, } \\
15-16\end{array}$ & $\begin{array}{l}\text { Treatment } \\
\text { group, 15- } \\
16\end{array}$ & $\begin{array}{l}\text { Control } \\
\text { group, 15- } \\
16\end{array}$ \\
\hline $\begin{array}{l}\text { \% of } \\
\text { correct } \\
\text { responses, } \\
\text { Q1 }\end{array}$ & 48.52 & 48.37 & 48.90 & 47.62 & 47.38 & 48.23 \\
\hline $\begin{array}{l}\text { \% of "Do } \\
\text { not know" } \\
\text { responses, } \\
\text { Q1 }\end{array}$ & 17.37 & 17.70 & 16.48 & 17.85 & 18.32 & 16.72 \\
\hline $\begin{array}{l}\% \text { of } \\
\text { incorrect } \\
\text { responses, } \\
\text { Q1 }\end{array}$ & 34.12 & 33.93 & 34.62 & 34.53 & 34.30 & 35.05 \\
\hline $\begin{array}{l}\text { \% of } \\
\text { correct } \\
\text { responses, } \\
\text { Q2 }\end{array}$ & 54.02 & 54.45 & 52.90 & 54.38 & 54.83 & 53.60 \\
\hline $\begin{array}{l}\text { \% of "Do } \\
\text { not know" } \\
\text { responses, } \\
\text { Q2 }\end{array}$ & 12.87 & 12.65 & 13.45 & 12.13 & 12.22 & 11.85 \\
\hline $\begin{array}{l}\text { \% of } \\
\text { incorrect } \\
\text { responses, } \\
\text { Q2 }\end{array}$ & 33.15 & 32.90 & 33.65 & 33.48 & 32.95 & 34.55 \\
\hline
\end{tabular}

Notes:

1) Q1: Questionnaire 1 (pre-test); Q2: Questionnaire 2 (post-test)

2) Number of observations: 2014-15: Q1: Treatment group $N=1,533$, Control group $N=594$; Q2: Treatment group $\mathrm{N}=1,302$, Control group $\mathrm{N}=514 ;$ 2015-2016: Q1: Treatment group $\mathrm{N}=1,406$, Control group $\mathrm{N}=678$; Q2: Treatment group $\mathrm{N}=1,198$, Control group $\mathrm{N}=597$. 
Table 4. Responses to the questions related to savings: means (standard errors in parentheses)

\begin{tabular}{|l|l|l|l|l|}
\hline & $\begin{array}{l}\text { Treatment group, } \\
2014-2015\end{array}$ & $\begin{array}{l}\text { Control group, } \\
2014-2015\end{array}$ & $\begin{array}{l}\text { Treatment } \\
\text { group, 2015- } \\
2016\end{array}$ & $\begin{array}{l}\text { Control } \\
\text { group, 2015- } \\
2016\end{array}$ \\
\hline $\begin{array}{l}\text { Saves regularly for } \\
\text { some goal, Q1 (\%) }\end{array}$ & $\begin{array}{l}58.5 \\
(1.3)\end{array}$ & $\begin{array}{l}56.1 \\
(2.0)\end{array}$ & $\begin{array}{l}56.3^{* *} \\
(1.3)\end{array}$ & $\begin{array}{l}51.2^{* *} \\
(1.9)\end{array}$ \\
\hline $\begin{array}{l}\text { Saves regularly for } \\
\text { some goal, Q2 (\%) }\end{array}$ & 57.8 & 55.1 & 51.8 & 54.8 \\
\hline $\begin{array}{l}\text { Often or always saves } \\
\text { from allowances, Q1 }\end{array}$ & 40.4 & $(2.2)$ & $(1.4)$ & $(2.0)$ \\
(\%) & $(1.3)$ & 40.2 & $42.0^{*}$ & $37.9^{*}$ \\
\hline $\begin{array}{l}\text { Often or always saves } \\
\text { from allowances, Q2 }\end{array}$ & $44.4^{* *}$ & $(2.0)$ & $(1.3)$ & $(1.9)$ \\
(\%) & $(1.4)$ & $38.7^{* *}$ & 41.5 & 41.2 \\
\hline Saves for the future, & 44.7 & $(2.2)$ & $(1.4)$ & $(2.0)$ \\
Q1 (\%) & $(1.2)$ & 41.4 & 41.7 & 40.9 \\
\hline Saves for the future, & 45.8 & $(2.0)$ & $(1.3)$ & $(1.9)$ \\
Q2 (\%) & $(1.4)$ & 41.6 & 44.1 & 42.2 \\
\hline Savings index, Q1 & 1.44 & $(2.2)$ & $(1.4)$ & $(2.0)$ \\
\hline Savings index, Q2 & $1.48^{* *}$ & 1.38 & $1.40^{* *}$ & $1.30^{* *}$ \\
& $(.03)$ & $1.35^{* *}$ & 1.37 & $1.04)$ \\
\hline
\end{tabular}

Notes:

1) Q1: Questionnaire 1 (pre-test); Q2: Questionnaire 2 (post-test)

2) Number of observations are: 2014-15: Q1: Treatment group $N=1,533$, Control group $N=594 ; \mathrm{Q} 2$ : Treatment group $\mathrm{N}=1,302$, Control group $\mathrm{N}=514 ; 2015-2016$ : Q1: Treatment group $\mathrm{N}=1,406$, Control group $\mathrm{N}=678 ; \mathrm{Q} 2$ : Treatment group $\mathrm{N}=1,198$, Control group $\mathrm{N}=597$.

3) The results of the t-test refer to pairwise comparisons of the treatment and control groups. Levels of significance: ${ }^{*} 10 \% ; * * 5 \%$. 
Table 5. Descriptive statistics for Onni participation in the sample: mean (standard deviations in parentheses)

\begin{tabular}{|l|l|l|}
\hline & $2014-2015$ & $2015-2016$ \\
\hline Participation in Onni, Q1 & 0.72 & 0.67 \\
& $(0.45)$ & $(0.47)$ \\
& $(\mathrm{N}=2127)$ & $(\mathrm{N}=2084)$ \\
\hline Participation in Onni, Q2 & 0.72 & 0.67 \\
& $(0.45)$ & $(0.47)$ \\
& $(\mathrm{N}=1816)$ & $(\mathrm{N}=1795)$ \\
\hline $\begin{array}{l}\text { Log-ins per student, Q2 } \\
\text { (intensity measure 1) }\end{array}$ & 1.70 & \\
& $(1.99)$ & \\
\hline Log-ins per student, Q2 & $(\mathrm{N}=1816)$ & \\
(treated students only) & $(1.37$ & \\
& $(\mathrm{N}=1302)$ & \\
\hline $\begin{array}{l}\text { Events per student, Q2 } \\
\text { (intensity measure 2) }\end{array}$ & & 17.98 \\
& & $(24.55)$ \\
\hline Events per student, Q2 & & $(\mathrm{N}=1795)$ \\
(treated students only) & & 26.94 \\
& & $(25.72)$ \\
& & $(\mathrm{N}=1198)$ \\
\hline
\end{tabular}


Table 6: Summary statistics of independent variables: Means (standard errors in parentheses)

\begin{tabular}{|l|l|l|l|l|}
\hline Variable & $\begin{array}{l}2014-2015, \\
\text { treatment }\end{array}$ & $\begin{array}{l}2014-2015, \\
\text { control }\end{array}$ & $\begin{array}{l}\text { 2015-2016, } \\
\text { treatment }\end{array}$ & $\begin{array}{l}\text { 2015-2016, } \\
\text { control }\end{array}$ \\
\hline Female, Q1 & 0.487 & 0.502 & 0.491 & 0.478 \\
& $(0.013)$ & $(0.021)$ & $(0.013)$ & $(0.019)$ \\
\hline Female, Q2 & 0.498 & 0.506 & 0.497 & 0.479 \\
& $(0.014)$ & $(0.022)$ & $(0.014)$ & $(0.020)$ \\
\hline Family talks often & 0.607 & 0.577 & $0.617^{* * * *}$ & $0.516^{* * *}$ \\
about money, Q1 & $(0.012)$ & $(0.020)$ & $(0.013)$ & $(0.020)$ \\
\hline Family talks often & $0.671^{*}$ & $0.628^{*}$ & $0.674^{* * *}$ & $0.605^{* * *}$ \\
about money, Q2 & $(0.013)$ & $(0.021)$ & $(0.014)$ & $(0.020)$ \\
\hline Has a bank & 0.818 & 0.795 & 0.826 & 0.811 \\
account, Q1 & $(0.010)$ & $(0.017)$ & $(0.010)$ & $(0.015)$ \\
\hline Has a bank & 0.843 & 0.825 & 0.847 & 0.829 \\
account, Q2 & $(0.010)$ & $(0.017)$ & $(0.010)$ & $(0.015)$ \\
\hline Plans ahead, Q1 & 0.783 & 0.808 & 0.797 & 0.779 \\
& $(0.011)$ & $(0.016)$ & $(0.011)$ & $(0.016)$ \\
\hline Plans ahead, Q2 & 0.841 & 0.842 & 0.831 & 0.849 \\
& $(0.010)$ & $(0.016)$ & $(0.011)$ & $(0.015)$ \\
\hline Earnings outside & $0.695 * *$ & $0.645^{* *}$ & $0.682 *$ & $0.638^{*}$ \\
family, Q1 & $(0.012)$ & $(0.020)$ & $(0.012)$ & $(0.018)$ \\
\hline Earnings outside & 0.680 & 0.645 & 0.647 & 0.642 \\
family, Q2 & $(0.013)$ & $(0.021)$ & $(0.014)$ & $(0.020)$ \\
\hline Receives regular & 0.344 & 0.354 & 0.348 & 0.355 \\
allowance, Q1 & $(0.012)$ & $(0.020)$ & $(0.013)$ & $(0.018)$ \\
\hline Receives regular & 0.363 & 0.383 & 0.361 & 0.363 \\
allowance, Q2 & $(0.013)$ & $(0.021)$ & $(0.014)$ & $(0.020)$ \\
\hline Math grade, Q2 & & & 7.737 & 7.801 \\
& & & $(0.045)$ & $(0.058)$ \\
\hline Average grade in & & & 8.007 & 8.054 \\
all subjects, Q2 & & $(0.029)$ & $(0.038)$ \\
\hline Less than 25 & & $0.209 * * *$ & $0.265^{* * *}$ \\
books at home, & & $(0.012)$ & $(0.018)$ \\
Q2 & & & 0.392 & 0.425 \\
\hline 25-100 books at & & & $0.399^{* * * *}$ & $(0.020)$ \\
home, Q2 & & & & $0.310^{* * *}$ \\
\hline $\begin{array}{l}\text { Over 100 books } \\
\text { at home, Q2 }\end{array}$ & & & & \\
\hline
\end{tabular}

Notes:

1) Q1: Questionnaire 1 (pre-test); Q2: Questionnaire 2 (post-test) 
2) Number of observations: $2014-2015, \mathrm{~N}$ is always 3,$943 ; 2015-2016, \mathrm{~N}$ is always 3,879 except for math grade, average grade in all subjects and the number of books at home, for which it is 3,352 .

3) The results of the t-test refer to pairwise comparisons of the treatment and control groups. Levels of significance: * $10 \%$; $* * 5 \%$; $* * 1 \%$. 
Table 7: Financial knowledge: Regression results for 2014-2015. OLS parameter coefficients, standard errors in parentheses.

\begin{tabular}{|c|c|c|c|c|c|c|}
\hline VARIABLES & Pre-test & Post-test & $\begin{array}{l}(3) \\
\text { Pre- \& } \\
\text { post-test }\end{array}$ & $\begin{array}{l}(4) \\
\text { Pre- \& } \\
\text { post-test }\end{array}$ & $\begin{array}{l}(5) \\
\text { Pre- \& } \\
\text { post-test }\end{array}$ & $\begin{array}{l}(6) \\
\text { Pre-\& } \\
\text { post-test }\end{array}$ \\
\hline Onni (treatment) & $\begin{array}{l}-0.438 \\
(0.357)\end{array}$ & $\begin{array}{l}0.786 * * \\
(0.369)\end{array}$ & $\begin{array}{l}-0.435 \\
(0.358)\end{array}$ & $\begin{array}{l}-0.449 \\
(0.357)\end{array}$ & $\begin{array}{l}-0.449 \\
(0.357)\end{array}$ & $\begin{array}{l}-0.450 \\
(0.357)\end{array}$ \\
\hline Post-education & & & $\begin{array}{l}2.145^{* * *} \\
(0.390)\end{array}$ & $\begin{array}{l}1.038 * * \\
(0.446)\end{array}$ & $\begin{array}{l}1.099 * * \\
(0.532)\end{array}$ & $\begin{array}{l}1.042 * * \\
(0.446)\end{array}$ \\
\hline $\begin{array}{l}\text { Onni* Post- } \\
\text { education }\end{array}$ & & & $\begin{array}{l}1.203 * * * \\
(0.451)\end{array}$ & $\begin{array}{l}1.226 * * * \\
(0.448)\end{array}$ & $\begin{array}{l}1.140^{*} \\
(0.601)\end{array}$ & $\begin{array}{l}0.599 \\
(0.501)\end{array}$ \\
\hline Female & $\begin{array}{l}-1.917^{* * *} \\
(0.326)\end{array}$ & $\begin{array}{l}0.410 \\
(0.325)\end{array}$ & $\begin{array}{l}-0.832 * * * \\
(0.259)\end{array}$ & $\begin{array}{l}-1.847^{* * *} \\
(0.325)\end{array}$ & $\begin{array}{l}-1.847^{* * *} \\
(0.325)\end{array}$ & $\begin{array}{l}-1.851 * * * \\
(0.325)\end{array}$ \\
\hline $\begin{array}{l}\text { Female* Post- } \\
\text { education }\end{array}$ & & & & $\begin{array}{l}2.200 * * * \\
(0.397)\end{array}$ & $\begin{array}{l}2.078 * * * \\
(0.678)\end{array}$ & $\begin{array}{l}2.194 * * * \\
(0.396)\end{array}$ \\
\hline \multicolumn{2}{|c|}{ Onni*Female*Post-education } & & & & $\begin{array}{l}0.171 \\
(0.739)\end{array}$ & \\
\hline $\begin{array}{l}\text { Family talks often } \\
\text { about money }\end{array}$ & $\begin{array}{l}2.128 * * * \\
(0.335)\end{array}$ & $\begin{array}{l}1.480 * * * \\
(0.367)\end{array}$ & $\begin{array}{l}1.872 * * * \\
(0.258)\end{array}$ & $\begin{array}{l}1.857 * * * \\
(0.257)\end{array}$ & $\begin{array}{l}1.856 * * * \\
(0.257)\end{array}$ & $\begin{array}{l}1.866 * * * \\
(0.257)\end{array}$ \\
\hline $\begin{array}{l}\text { Has a bank } \\
\text { account }\end{array}$ & $\begin{array}{l}2.026 * * * \\
(0.449)\end{array}$ & $\begin{array}{l}2.539 * * * \\
(0.522)\end{array}$ & $\begin{array}{l}2.247 * * * \\
(0.359)\end{array}$ & $\begin{array}{l}2.225^{* * *} \\
(0.360)\end{array}$ & $\begin{array}{l}2.225^{* * *} \\
(0.359)\end{array}$ & $\begin{array}{l}2.230 * * * \\
(0.360)\end{array}$ \\
\hline Plans ahead & $\begin{array}{l}2.935 * * * \\
(0.434)\end{array}$ & $\begin{array}{l}2.683 * * * \\
(0.513)\end{array}$ & $\begin{array}{l}2.828 * * * \\
(0.342)\end{array}$ & $\begin{array}{l}2.836 * * * \\
(0.342)\end{array}$ & $\begin{array}{l}2.838 * * * \\
(0.342)\end{array}$ & $\begin{array}{l}2.849 * * * \\
(0.341)\end{array}$ \\
\hline $\begin{array}{l}\text { Earns income } \\
\text { outside of family }\end{array}$ & $\begin{array}{l}1.045^{* * *} \\
(0.362)\end{array}$ & $\begin{array}{l}1.844^{* * *} \\
(0.360)\end{array}$ & $\begin{array}{l}1.417^{* * *} \\
(0.276)\end{array}$ & $\begin{array}{l}1.404 * * * \\
(0.276)\end{array}$ & $\begin{array}{l}1.404^{* * *} \\
(0.276)\end{array}$ & $\begin{array}{l}1.423 * * * \\
(0.276)\end{array}$ \\
\hline $\begin{array}{l}\text { Receives regular } \\
\text { allowance from } \\
\text { family }\end{array}$ & $\begin{array}{l}-0.856 * * \\
(0.345)\end{array}$ & $\begin{array}{l}0.275 \\
(0.336)\end{array}$ & $\begin{array}{l}-0.305 \\
(0.261)\end{array}$ & $\begin{array}{l}-0.321 \\
(0.261)\end{array}$ & $\begin{array}{l}-0.322 \\
(0.261)\end{array}$ & $\begin{array}{l}-0.383 \\
(0.263)\end{array}$ \\
\hline $\begin{array}{l}\text { Onni, intensity of } \\
\text { use }\end{array}$ & & & & & & $\begin{array}{l}0.264^{* * *} \\
(0.0895)\end{array}$ \\
\hline Constant & $\begin{array}{l}24.72 * * * \\
(0.689)\end{array}$ & $\begin{array}{l}24.94 * * * \\
(0.841)\end{array}$ & $\begin{array}{l}21.65 * * * \\
(0.769)\end{array}$ & $\begin{array}{l}23.30 * * * \\
(0.839)\end{array}$ & $\begin{array}{l}23.24 * * * \\
(0.911)\end{array}$ & $\begin{array}{l}23.29 * * * \\
(0.839)\end{array}$ \\
\hline Observations & 2,127 & 1,816 & 3,943 & 3,943 & 3,943 & 3,943 \\
\hline R-squared & 0.081 & 0.089 & 0.119 & 0.124 & 0.124 & 0.126 \\
\hline $\begin{array}{l}\text { F-test } \\
\text { Notes: }\end{array}$ & $21.99 * * *$ & $14.76^{* * *}$ & $58.12 * * *$ & $58.44^{* * *}$ & $53.13^{* * *}$ & $55.30 * * *$ \\
\hline $\begin{array}{l}\text { 1) Standard } \\
\text { 2) Levels of }\end{array}$ & $\begin{array}{l}\text { rs are hete } \\
\text { istical signif }\end{array}$ & reskedasticit & $\begin{array}{l}y-\text { and clus } \\
6 ; * * 5 \% ;\end{array}$ & $\begin{array}{l}\text { robust. } \\
\% .\end{array}$ & & \\
\hline
\end{tabular}


Table 8: Financial knowledge: Regression results for the 2015-2016 period. OLS parameter coefficients, standard errors in parentheses. (TABLE CONTINUES TO THE NEXT PAGE)

\begin{tabular}{|c|c|c|c|c|c|c|c|c|}
\hline VARIABLES & Pre-test & Post-test & Post-test & $\begin{array}{l}(4) \\
\text { Pre- \& post- } \\
\text { test }\end{array}$ & $\begin{array}{l}(5) \\
\text { Pre- \& post- } \\
\text { test }\end{array}$ & $\begin{array}{l}(6) \\
\text { Pre-\& post- } \\
\text { test }\end{array}$ & $\begin{array}{l}\text { (7) } \\
\text { Pre- \& post- } \\
\text { test }\end{array}$ & $\begin{array}{l}\text { (8) } \\
\text { Pre- \& post- } \\
\text { test }\end{array}$ \\
\hline Onni & $-0.784^{* *}$ & $0.647^{*}$ & $0.755^{* *}$ & $-2.228 * * *$ & $-2.180 * * *$ & $-1.951^{* * *}$ & $-2.182 * * *$ & $-1.562 * *$ \\
\hline (treatment) & $(0.346)$ & $(0.348)$ & $(0.335)$ & $(0.693)$ & $(0.691)$ & $(0.742)$ & $(0.691)$ & $(0.729)$ \\
\hline \multirow[t]{2}{*}{ Post-education } & & & & $2.861^{* * *}$ & $1.851^{* * *}$ & $1.697^{* * *}$ & $1.708^{* * *}$ & $1.863^{* * *}$ \\
\hline & & & & $(0.349)$ & $(0.395)$ & $(0.395)$ & $(0.414)$ & $(0.395)$ \\
\hline Onni * & & & & $1.438^{* * *}$ & $1.403^{* * *}$ & $1.324^{* * *}$ & $1.623^{* * *}$ & $0.837^{*}$ \\
\hline Post-education & & & & $(0.426)$ & $(0.424)$ & (0.429) & $(0.465)$ & (0.479) \\
\hline \multirow[t]{2}{*}{ Female } & $-1.337 * * *$ & $0.615^{*}$ & $-0.660 *$ & -0.427 & $-3.512 * * *$ & $-4.969 * * *$ & $-3.504 * * *$ & $-3.548 * * *$ \\
\hline & $(0.330)$ & $(0.338)$ & $(0.363)$ & $(0.264)$ & $(0.653)$ & (0.719) & $(0.653)$ & $(0.657)$ \\
\hline Female* & & & & & $2.105^{* * *}$ & $2.399 * * *$ & $2.403^{* * *}$ & $2.106 * * *$ \\
\hline Post-education & & & & & $(0.401)$ & $(0.411)$ & $(0.456)$ & $(0.402)$ \\
\hline Onni*Female & & & & & & & -0.451 & \\
\hline *Post-education & & & & & & & $(0.342)$ & \\
\hline $\begin{array}{l}\text { Family often } \\
\text { talks about }\end{array}$ & $1.394 * * *$ & $1.456^{* * *}$ & $1.372^{* * *}$ & $1.415^{* * *}$ & $1.413^{* * *}$ & $1.136^{* * *}$ & $1.407^{* * *}$ & $1.365^{* * *}$ \\
\hline money & $(0.336)$ & $(0.379)$ & $(0.366)$ & $(0.267)$ & $(0.267)$ & $(0.281)$ & $(0.267)$ & $(0.269)$ \\
\hline \multirow[t]{2}{*}{ Bank account } & $2.957^{* * *}$ & $1.592^{* * *}$ & $0.859 *$ & $2.333^{* * *}$ & $2.376^{* * *}$ & $1.574 * * *$ & $2.373^{* * *}$ & $2.381 * * *$ \\
\hline & $(0.459)$ & $(0.501)$ & $(0.494)$ & $(0.352)$ & $(0.352)$ & $(0.376)$ & $(0.352)$ & $(0.353)$ \\
\hline \multirow[t]{2}{*}{ Plans ahead } & $2.416 * * *$ & $3.179 * * *$ & $2.305^{* * *}$ & $2.681^{* * *}$ & $2.721 * * *$ & $1.732^{* * *}$ & $2.723^{* * *}$ & $2.608 * * *$ \\
\hline & $(0.444)$ & $(0.536)$ & $(0.528)$ & $(0.361)$ & $(0.362)$ & $(0.396)$ & $(0.362)$ & $(0.364)$ \\
\hline Earns income & $1.587^{* * *}$ & $1.173^{* * *}$ & $1.022^{* * *}$ & $1.432^{* * *}$ & $1.392^{* * *}$ & $1.211^{* * *}$ & $1.390^{* * *}$ & $1.383^{* * *}$ \\
\hline outside family & $(0.357)$ & $(0.360)$ & $(0.346)$ & $(0.268)$ & $(0.268)$ & $(0.281)$ & $(0.267)$ & $(0.269)$ \\
\hline Receives regular & 0.221 & $-0.627^{*}$ & -0.264 & -0.161 & -0.170 & -0.0697 & -0.163 & -0.176 \\
\hline allowance & $(0.340)$ & $(0.347)$ & $(0.337)$ & $(0.264)$ & $(0.264)$ & $(0.279)$ & $(0.265)$ & $(0.267)$ \\
\hline \multirow[t]{2}{*}{ Math grade } & & & $0.356^{* *}$ & & & $0.304^{* *}$ & & \\
\hline & & & $(0.177)$ & & & $(0.148)$ & & \\
\hline \multirow[t]{2}{*}{ Grade, all subjects } & & & $1.605^{* * *}$ & & & $1.059 * * *$ & & \\
\hline & & & $(0.283)$ & & & $(0.247)$ & & \\
\hline \multirow[t]{2}{*}{$26-100$ books } & & & 0.380 & & & 0.261 & & \\
\hline & & & $(0.429)$ & & & $(0.367)$ & & \\
\hline \multirow[t]{2}{*}{ Over 100 books } & & & 0.358 & & & 0.462 & & \\
\hline & & & $(0.462)$ & & & $(0.395)$ & & \\
\hline
\end{tabular}


Constant

$\begin{array}{llllllll}23.49^{* * *} & 26.44^{* * *} & 12.44^{* * *} & 20.72^{* * *} & 22.16^{* * *} & 13.48^{* * *} & 22.16^{* * *} & 22.28^{* * *} \\ (0.634) & (0.739) & (1.575) & (0.717) & (0.756) & (1.454) & (0.756) & (0.758)\end{array}$

Observations

\begin{tabular}{llll}
\multicolumn{1}{r}{2,084} & \multicolumn{1}{r}{1,795} & \multicolumn{1}{r}{1,795} & \multicolumn{1}{r}{3,87} \\
0.076 & 0.066 & 0.133 & 0.128 \\
$21.79^{* * *}$ & $14.41^{* * *}$ & $21.11^{* * *}$ & $69.32^{* * *}$
\end{tabular}

0.133
$66.73^{* * *}$

3,352

0.151

3,879

R-squared

$21.79 * * *$

$14.41^{* * *}$

$21.11^{* * *}$

$69.32^{* * *}$

$47.77^{* * *}$

$60.70^{* * *}$

3,839

Notes:

1) Standard errors are heteroskedasticity- and cluster-robust.

2) Levels of statistical significance: ${ }^{*} 10 \% ;{ }^{* *} 5 \%$; ${ }^{* *} 1 \%$. 
Table 9: Savings behaviour: Regression results for 2014-2015. OLS parameter coefficients, standard errors in parentheses.
(1)
(2)
(3)
(4)
(5)
(6)
(7)

VARIABLES

Onni

(treatment)

Post-education

Onni*

Post-education

Female

Female*

Post-education

Onni * Female

* Post-education

Family often

talks about money

0.190 ***

$0.300 * * *$

$0.240^{* * *}$

$0.239 * * *$

$0.238^{* * *}$

$0.238^{* * *}$

$0.220^{* * *}$

$$
\text { (0.0459) }
$$

(0.0534)

$(0.0374)$

(0.0374)

(0.0374)

(0.0374)

(0.0378)

Bank account

\subsection{5}

0.0626

0.0672

0.0662

0.0659

0.0657

0.0435

(0.0578)

(0.0685)

$(0.0467)$

$(0.0467)$

(0.0467)

(0.0467)

(0.0468)

Plans ahead

$$
0.430 * * *
$$

$0.379 * * *$

$0.407^{* * *}$

$0.408 * * *$

$0.409 * * *$

$0.406 * * *$

(0.0553)

(0.0693)

(0.0458)

(0.0458)

(0.0458)

(0.0457)

$0.379 * * *$

Earns income

outside family

0.119**

$0.181^{* *}$

$0.151^{* * *}$

$0.151 * *$

$0.151^{* * *}$

$0.149 * * *$

(0.0489)

(0.0542)

$(0.0397)$

$(0.0397)$

(0.0397)

(0.0397)

$0.136^{* * *}$

Receives

regular allowance

$-0.0363$

0.00924

$-0.0148$

$-0.0155$

$-0.0163$

$-0.00855 \quad-0.0123$

(0.0474)

(0.0523)

(0.0400)

(0.0400)

(0.0400)

(0.0401)

(0.0399)

Onni, intensity

of use

Financial
$-0.0299 * *$

(0.0142) 


\begin{tabular}{|c|c|c|c|c|c|c|c|}
\hline Constant & $\begin{array}{l}0.805 * * * \\
(0.0815)\end{array}$ & $\begin{array}{l}0.621 * * * \\
(0.0924)\end{array}$ & $\begin{array}{l}0.792 * * * \\
(0.0981)\end{array}$ & $\begin{array}{l}0.871 * * * \\
(0.105)\end{array}$ & $\begin{array}{l}0.824 * * * \\
(0.112)\end{array}$ & $\begin{array}{l}0.872^{* * *} \\
(0.105)\end{array}$ & $\begin{array}{l}0.633 * * * \\
(0.117)\end{array}$ \\
\hline Observations & 2,127 & 1,816 & 3,943 & 3,943 & 3,943 & 3,943 & 3,943 \\
\hline R-squared & 0.047 & 0.059 & 0.051 & 0.052 & 0.052 & 0.053 & 0.056 \\
\hline F-test & $15.77^{* * *}$ & $16.64 * * *$ & $20.93 * * *$ & $19.38 * * *$ & $17.77 * * *$ & $18.09 * * *$ & $20.01 * * *$ \\
\hline \multicolumn{8}{|c|}{ Robust standard errors in parentheses } \\
\hline$* * p<0.01, * *$ & $<0.1$ & & & & & & \\
\hline
\end{tabular}

Notes:

1) Standard errors are heteroskedasticity- and cluster-robust.

2) Levels of statistical significance: ${ }^{*} 10 \%$; ${ }^{* *} 5 \% ;{ }^{* * *} 1 \%$. 
Table 10: Savings behaviour: Regression results for the 2015-2016 academic year. OLS parameter coefficients, standard errors in parentheses. (TABLE CONTINUES TO THE NEXT PAGE)

\begin{tabular}{|c|c|c|c|c|c|c|c|c|c|}
\hline VARIABLES & Pre-test & Post-test & Post-test & $\begin{array}{l}(4) \\
\text { Pre\& } \\
\text { post- }\end{array}$ & $\begin{array}{l}(5) \\
\text { Pre\& } \\
\text { post- }\end{array}$ & $\begin{array}{l}(6) \\
\text { Pre\& } \\
\text { post- }\end{array}$ & $\begin{array}{l}(7) \\
\text { Pre\& } \\
\text { post- }\end{array}$ & $\begin{array}{l}(8) \\
\text { Pre\& } \\
\text { post- }\end{array}$ & $\begin{array}{l}(9) \\
\text { Pre\& } \\
\text { post- }\end{array}$ \\
\hline Onni & 0.0766 & -0.0168 & -0.00474 & $0.161^{*}$ & $0.163^{*}$ & $0.162 *$ & $0.183^{*}$ & $0.249 * * *$ & $0.187^{* *}$ \\
\hline (treatment) & $(0.0487)$ & (0.0519) & $(0.0508)$ & $(0.0867)$ & $(0.0867)$ & $(0.0867)$ & $(0.0940)$ & $(0.0927)$ & $(0.0865)$ \\
\hline \multirow[t]{2}{*}{ Post-education } & & & & $\begin{array}{l}0.0383 \\
(0.0427)\end{array}$ & $\begin{array}{l}0.00285 \\
(0.0496)\end{array}$ & $\begin{array}{l}-0.00848 \\
(0.0522)\end{array}$ & $\begin{array}{l}-0.00890 \\
(0.0494)\end{array}$ & $\begin{array}{l}0.00856 \\
(0.0496)\end{array}$ & $\begin{array}{l}-0.0176 \\
(0.0495)\end{array}$ \\
\hline & & & & & & & & - & \\
\hline Onni* & & & & $-0.0870 *$ & $-0.0883^{*}$ & -0.0708 & $-0.0928^{*}$ & $0.170 * * *$ & $-0.104 * *$ \\
\hline Post-education & & & & $(0.0523)$ & $(0.0523)$ & $(0.0585)$ & $(0.0521)$ & $(0.0612)$ & $(0.0522)$ \\
\hline \multirow[t]{2}{*}{ Female } & 0.0295 & 0.0809 & $-0.119 * *$ & 0.0517 & -0.0566 & -0.0561 & $-0.213^{* *}$ & -0.0437 & -0.0179 \\
\hline & $(0.0461)$ & $(0.0498)$ & $(0.0524)$ & $(0.0406)$ & $(0.0818)$ & $(0.0819)$ & $(0.0879)$ & $(0.0822)$ & $(0.0823)$ \\
\hline Female* & & & & & 0.0739 & 0.0976 & 0.0523 & 0.0646 & 0.0507 \\
\hline Post-education & & & & & $(0.0498)$ & $(0.0604)$ & $(0.0493)$ & $(0.0498)$ & $(0.0501)$ \\
\hline Onni * Female & & & & & & -0.0358 & & & \\
\hline * Post-education & & & & & & (0.0539) & & & \\
\hline Family often & $0.0977^{* *}$ & $0.170 * * *$ & $0.154^{* * *}$ & $0.127^{* * *}$ & $0.127^{* * *}$ & $0.127^{* * *}$ & $0.114 * * *$ & $0.121^{* * *}$ & $0.111 * * *$ \\
\hline talks about money & $(0.0463)$ & $(0.0523)$ & $(0.0506)$ & $(0.0378)$ & $(0.0378)$ & $(0.0378)$ & $(0.0403)$ & $(0.0381)$ & $(0.0379)$ \\
\hline \multirow[t]{2}{*}{ Bank account } & $0.132 * *$ & $0.170 * * *$ & 0.0595 & $0.148 * * *$ & $0.150^{* * *}$ & $0.150 * * *$ & 0.0596 & $0.151^{* * *}$ & $0.124 * *$ \\
\hline & $(0.0585)$ & $(0.0652)$ & $(0.0637)$ & $(0.0479)$ & $(0.0480)$ & $(0.0479)$ & $(0.0502)$ & $(0.0481)$ & $(0.0482)$ \\
\hline \multirow[t]{2}{*}{ Plans ahead } & $0.409 * * *$ & $0.438^{* * *}$ & $0.311^{* * *}$ & $0.420 * * *$ & $0.421 * * *$ & $0.421 * * *$ & $0.261 * * *$ & $0.411^{* * *}$ & $0.391 * * *$ \\
\hline & $(0.0548)$ & $(0.0647)$ & $(0.0640)$ & $(0.0439)$ & $(0.0440)$ & $(0.0440)$ & $(0.0479)$ & $(0.0443)$ & $(0.0444)$ \\
\hline Earns income & $0.127^{* * *}$ & 0.0496 & 0.0273 & $0.0928 * *$ & $0.0914^{* *}$ & $0.0913^{* *}$ & $0.0871^{* *}$ & $0.0940 * *$ & $0.0760 *$ \\
\hline outside family & $(0.0488)$ & $(0.0520)$ & $(0.0504)$ & $(0.0387)$ & $(0.0388)$ & $(0.0388)$ & $(0.0406)$ & $(0.0390)$ & $(0.0388)$ \\
\hline Receives & $0.110 * *$ & -0.0371 & 0.0165 & 0.0423 & 0.0420 & 0.0425 & 0.0475 & 0.0428 & 0.0439 \\
\hline regular allowance & $(0.0470)$ & $(0.0512)$ & $(0.0496)$ & $(0.0398)$ & $(0.0398)$ & $(0.0399)$ & $(0.0420)$ & $(0.0401)$ & $(0.0397)$ \\
\hline \multirow[t]{2}{*}{ Math grade } & & & 0.0221 & & & & 0.0270 & & \\
\hline & & & $(0.0249)$ & & & & $(0.0225)$ & & \\
\hline Average grade, & & & $0.261 * * *$ & & & & $0.257 * * *$ & & \\
\hline
\end{tabular}




\begin{tabular}{|c|c|c|c|c|c|c|c|c|c|}
\hline all subjects & & & $(0.0411)$ & & & & $(0.0366)$ & & \\
\hline $25-100$ books & & & $\begin{array}{l}0.193 * * * \\
(0.0623)\end{array}$ & & & & $\begin{array}{l}0.175 * * * \\
(0.0562)\end{array}$ & & \\
\hline 100- books & & & $\begin{array}{l}0.146 * * \\
(0.0663)\end{array}$ & & & & $\begin{array}{l}0.129 * * \\
(0.0589)\end{array}$ & & \\
\hline $\begin{array}{l}\text { Onni, intensity } \\
\text { of use }\end{array}$ & & & & & & & & $\begin{array}{l}0.00291 * * \\
(0.00110)\end{array}$ & \\
\hline $\begin{array}{l}\text { Financial } \\
\text { knowledge }\end{array}$ & & & & & & & & & $\begin{array}{l}0.0110 * * * \\
(0.00239)\end{array}$ \\
\hline Constant & $\begin{array}{l}0.690 * * * \\
(0.0775)\end{array}$ & $\begin{array}{l}0.709 * * * \\
(0.0932)\end{array}$ & $\begin{array}{l}- \\
1.396^{* * *} \\
(0.215)\end{array}$ & $\begin{array}{l}0.649 * * * \\
(0.0877)\end{array}$ & $\begin{array}{l}0.700 * * * \\
(0.0944)\end{array}$ & $\begin{array}{l}0.700^{* * *} \\
(0.0943)\end{array}$ & $\begin{array}{l}- \\
1.358^{* * *} \\
(0.207)\end{array}$ & $\begin{array}{l}0.701^{* * *} \\
(0.0947)\end{array}$ & $\begin{array}{l}0.455^{* * *} \\
(0.108)\end{array}$ \\
\hline Observations & 2,084 & 1,795 & 1,795 & 3,879 & 3,879 & 3,879 & 3,352 & 3,839 & 3,879 \\
\hline R-squared & 0.043 & 0.041 & 0.110 & 0.041 & 0.041 & 0.041 & 0.108 & 0.041 & 0.047 \\
\hline F-test & $14.70^{* * *}$ & $12.02 * * *$ & $22.79 * * *$ & $17.26 * * *$ & $15.64 * * *$ & $14.27 * * *$ & $23.10 * * *$ & $14.23 * * *$ & $16.57^{* * *}$ \\
\hline
\end{tabular}

Notes:

1) Standard errors are heteroskedasticity- and cluster-robust.

2) Levels of statistical significance: $* 10 \% ; * * 5 \% ; * * * 1 \%$. 
Appendix. Examples of Knowledge Questions (correct answers in bold)

A1. 15-year-old can independently sign a work contract and resign from work: True / untrue / do not know

A2. The right to exchange and return products to shops is voluntary service provided by the shops, and the shops can define the conditions under which these returns may occur: True / untrue / do not know

A3. Electronic bills can be paid only in bank branches: True / untrue / do not know

A4. You can control investment risk by investing as much as possible in one asset only: True / untrue / do not know

A5. Home insurance is mandatory: True / untrue / do not know 